\title{
RELIABILITA A KONSTRUKTOVÁ VALIDITA METODY RELATIONSHIP ASSESSMENT SCALE
}

\author{
NiKol Kvardová ${ }^{1}$, Monika RadimeCKÁ ${ }^{1}$, MaRIE DRÁPALOVÁ ${ }^{1}$, JAN ŠIRŮČEK ${ }^{1}$ \\ ${ }^{1}$ Katedra psychologie, Fakulta sociálních studií Masarykovy univerzity
}

\begin{abstract}
Abstrakt: Předkládaná studie se zabývala ověrením vybraných psychometrických charakteristik metody Relationship Assessment Scale (RAS), která zjištuje partnerskou spokojenost. V rámci ověření byla zjišt’ována reliabilita metody v podobě vnitřní konzistence a konstruktová validita prostřednictvím souvislosti metody RAS s dimenzemi partnerské spokojenosti, partnerské shody a partnerské soudržnosti metody Revised Dyadic Adjustment Scale (RDAS), která zjišt'uje partnerské přizpůsobení. Za účelem ověření těchto vlastností metody byla sesbírána data od 232 respondentü, data byla sesbírána po internetu. Reliabilita metody byla $v$ rámci současné studie zjištěna jako uspokojivá pro výzkumné účely. Souvislosti mezi faktorem partnerské spokojenosti metody RAS a faktory partnerské spokojenosti a soudržnosti metody RDAS podpořily hypotézu o konstruktové validitě metody RAS. Silný pozitivní vztah mezi faktorem partnerské spokojenosti metody RAS a faktorem partnerské shody metody RDAS nepodpořil hypotézu o konstruktové validitě, tento výsledek poukazoval na možnou shodu těchto dvou konstruktů. Výsledek však mohl být zpưsoben škálou partnerské shody metody RDAS, která na výzkumném vzorku současné studie nemusela fungovat jako spolehlivý ukazatel shody mezi partnery. Na základě výsledků byla navržena revize modelu.
\end{abstract}

Klíčová slova: Relationship Assessment Scale; partnerská spokojenost; psychometrické charakteristiky

\section{Úvod}

Spokojenost v partnerském vztahu je jedním z hlavních kritérií, která se používají při jeho hodnocení. Člověk považuje svůj partnerský vztah za spokojený tehdy, když naplňuje jeho vnitřně vnímané aspekty spokojeného vztahu a pokud žádný ze svých dalších vztahů nevnímá jako stejně spokojený (Thibaut \& Kelley, 1959). Vaughnová a Baierová (1999) zjistily, že vztahová spokojenost stoupá, pokud stoupají i vnímané odměny ze vztahu jako například vřelost a zároveň, když je vztah vnímán jako spravedlivý. Spokojenost také

\footnotetext{
${ }^{1}$ Katedra psychologie, Fakulta sociálních studií MU, Joštova 10, 602 00, Brno

Doručeno do redakce: 6. 12. 2018
} 
stoupá, pokud je podíl odměn a nákladů vložených do současného vztahu ve srovnání s ostatními vztahy považován za uspokojivý (Vaughn \& Baier, 1999). Spokojenost ve vztahu bývá měřena pomocí metod hodnotících pocity, myšlenky a chování partnerů ve vztahu či v manželství (Hendrick, 1988).

Mezi jeden $\mathrm{z}$ nejměřenějších konceptů $\mathrm{v}$ oblasti manželské a párové psychologie patří přizpůsobení se v partnerském vztahu (Spanier, 1985). Škály pro jeho měření byly vyvinuty za účelem poskytnout větší množství informací o vztazích, než které poskytovaly škály zaměřující se pouze na spokojenost (Spanier, 1976). Přizpůsobení se bývá popisováno jako dynamický proces, jehož výsledky jsou determinovány stupněm rozdílností $\mathrm{v}$ manželství, interpersonálního napětí a osobní úzkosti, spokojenosti partnerů, soudržnosti a shody ohledně důležitých záležitostí (Spanier, 1976). Busby, Crane, Larson a Christensen (1995) identifikovali jako faktory partnerského přizpůsobení soudržnost, shodu a spokojenost.

Soudržnost je chápána jako míra toho, jak moc jsou partneři emocionálně propojeni (Muraru \& Turliuc, 2013). Je spojena s dalšími aspekty, jako je „koalice“ páru, zájmy, rekreační činnosti, rozhodování a pouto mezi partnery (Olson \& Gorall, 2003).

Shoda se vztahuje k rozhodování o záležitostech týkajících se partnerského vztahu, odkazuje na stabilitu páru a taktéž konflikty mezi partnery (Muraru \& Turliuc, 2013). Vzhledem $\mathrm{k}$ tomu, že úzce souvisí s ostatními aspekty vztahové spokojenosti, je řazena mezi nejčastěji používané ukazatele kvality partnerského vztahu (Cramer, 2001). Výzkum Cramerové (2001) podpořil hypotézu o partnerské shodě a spokojenosti jako dvou odlišných konstruktech. Podle Hendrickové (1988) byl mezi faktorem spokojenosti a shody zjištěn středně silný vztah $(r=0,62)$, podobně jako mezi faktorem spokojenosti a soudržnosti $(r=0,57)$.

\section{Relationship Assessment Scale (RAS)}

Relationship Assessment Scale (Hendrick, 1988) je dotazníková metoda, která byla vyvinuta k měření spokojenosti ve vztahu. Dotazník je složen ze sedmi položek, na které respondent odpovídá na Likertově škále od 1 (nízká spokojenost) do 5 (vysoká spokojenost) podle toho, jak spokojený je s daným aspektem vztahu, na který určitá položka odkazuje.

Cronbachova alfa byla zjištěna $\alpha=0,91$, což poukazuje na vysokou vnitřní konzistenci, faktorová analýza metody podpořila hypotézu o unidimenzionální faktorové struktuře (Vaughn \& Baier, 1999). Výzkumný vzorek tvořilo 118 respondentů (53 mužů a 65 žen) ve věku 18 až 54 let $(M=32,63, S D=8,55)$. Jednodimenzionální faktorový model ukázal vysoké faktorové náboje a dobrou shodu modelu vzhledem $\mathrm{k}$ datům: $\mathrm{TLI}=0,95, \mathrm{CFI}=0,97$ a RMSEA = 0,06 (Renshaw, McKnight, Caska, \& Blais, 2010). V této studii sběr dat probíhal ve čtyřech etapách. První výzkumný vzorek, který byl sesbírán v roce 2006, tvořilo 479 respondentů. $Z$ výzkumného vzorku bylo $51 \%$ mužů, věkové rozpětí bylo 17 až 46 let ( $M=20,46, S D=3,80$ ). Druhý výzkumný vzorek byl sesbírán v roce 2008 a tvořilo ho 391 
respondentů. Přibližně 54,5 \% vzorku byli muži, věkové rozpětí bylo 17 až 49 let ( $M=20,61, S D=3,95)$. Výzkumný vzorek tři a čtyři byl sesbírán online a tvořili ho studenti psychologie. Velikost třetího vzorku byla 321 respondentů, z toho bylo 63,1 \% žen, věkové rozpětí bylo 17 až 45 let $(M=21,01, S D=3,78)$. Poslední vzorek byl tvořen 146 respondenty, z čehož bylo $62,8 \%$ žen a věkové rozpětí bylo 18 až 53 let $(M=22,64$, $\mathrm{SD}=5,60)$.

Metoda není omezena na měření spokojenosti pouze u sezdaných párů, ale je široce aplikovatelná na různé typy partnerských vztahů (partnerská spokojenost na počátku vztahu, páry ve společném soužití, páry, které se pouze scházejí - tzv. dating couples) (Vaughn \& Baier, 1999). Je také úspěšným indikátorem toho, zda partneři ve vztahu zůstanou, nebo se vztah rozpadne. Ve výzkumu Hendrickové (1988) RAS úspěšně identifikoval 91 \% lidí, kteří zůstali ve vztahu, a 86 \% těch, kterým vztah nevydržel, čímž byla podpořena prediktivní validita metody.

\section{Revised Dyadic Adjustment Scale (RDAS)}

Revised dyadic adjustment scale (Busby et al., 1995) je metoda k měření míry přizpůsobení v partnerském vztahu. Položky se zaměřují na zjištění partnerské shody, spokojenosti ve vztahu a partnerské soudržnosti. Původní metoda obsahuje čtrnáct položek, na které se odpovídá prostřednictvím Likertovy škály. Položky týkající se partnerské shody byly měřeny na škále od 0 (nikdy se neshodneme) do 5 (vždy se shodneme). Položky zjištujuící partnerskou spokojenost byly měřeny na škále od 0 (neustále) do 5 (nikdy), čímž byla zjišt'ována četnost výskytu určitých aktivit. Pro položky zjišt’ující partnerskou soudržnost byla použita škála od 0 (nikdy) do 5 (častěji než jednou denně), s výjimkou položky P16 (Věnujete se společně s partnerem nějakému zájmu?), kde byla použita škála od 4 (každý den) po 0 (nikdy).

Vnitřní konzistence jednotlivých škál byla odhadnuta jako přijatelná, pro škálu partnerské shody $\alpha=0,81$, škálu partnerské spokojenosti $\alpha=0,85$ a škálu partnerské soudržnosti $\alpha=0,80$ (Turliuc \& Muraru, 2013). Trojdimenzionální faktorový model ukázal vysoké faktorové náboje a dobrou shodu modelu vzhledem $\mathrm{k}$ datům: RMSEA $=0,08, T L I=0,92, C F I=0,93$ (Turliuc \& Muraru, 2013). Jejich výzkumný vzorek byl tvořen 383 respondenty, z čehož bylo 141 mužů a 242 žen. Průměrný věk byl 37,5 $(\min =20, \max =60, \mathrm{SD}=7,4)$.

\section{Cíle studie}

Cílem studie bylo adaptovat metodu Relationship Assessment Scale (RAS) do českého jazyka, metodu administrovat a ověřit její psychometrické vlastnosti - reliabilitu a konstruktovou validitu na základě souvislostí s dimenzemi metody Revised Dyadic Assessment Scale (RDAS). Mezi faktorem spokojenosti metody RAS a RDAS byl očekáván silný pozitivní vztah, jelikož jde o stejný konstrukt, který je oběma metodami měřen. Mezi faktorem spokojenosti metody RAS a faktory shody a soudržnosti metody RDAS byl očekáván středně silný vztah (Hendrick, 1988). 


\section{Metoda}

\section{Adaptace}

Jako způsob adaptace metody byl zvolen pouze překlad. Nebyl důvod předpokládat, že by se pojetí partnerské spokojenosti v českém kulturním prostředí odlišovalo natolik, aby byla tato odlišnost zdrojem rozdílných výsledků. Metoda byla přeložena a zpětným překladem ověřena autory studie. Rozdíly mezi originálním zněním položek a zpětným překladem byly zjištěny u položek P2 (Jak jste obecně spokojen/a se svým vztahem?), P3 (Jak dobrý je Váš vztah v porovnání s ostatními vztahy?), P4 (Jak často si prejete, abyste nebyl/a ve vztahu?), P5 (Do jaké míry naplňuje Váš vztah Vaše původní očekávání?) a P7 (Kolik je ve Vašem vztahu problémů?). Zjištěné rozdíly však byly pouze drobné odchylky v použitých slovech nebo slovosledu. U položky P3 Uak dobrý je Váš vztah v porovnání s ostatními vztahy?), která v anglickém originálu zněla „How good is your relationship compared to most?" byla provedena změna ve znění položky - spojení „compared to most" bylo nahrazeno „v porovnání s ostatními vztahy“, což je dle našeho názoru v češtině smysluplnějším slovním spojením, než „v porovnání s většinou vztahü“, což by odpovídalo doslovnému překladu. Rozdíly v překladu byly posouzeny autory studie, kteří došli $\mathrm{k}$ názoru, že žádný z nich nezpůsobil významový posun na úrovni jednotlivých slov ani celé položky.

Pro administraci metody RDAS byl použit český překlad Daňsové (2015), který byl vytvořen v rámci diplomové práce. Ve studii Daňsové (2015) byl překlad použit na vzorku 339 žen ve věku 17 až 45 let $(M=29,63, S D=4,51)$. Byla odstraněna položka týkající se shody partnerů v otázce víry a náboženství, protože v současném českém prostředí není otázka aktuální a k našemu měřenému konstruktu relevantní (podle průzkumu Hamplové a Řehákové (2009) uvádí 54 \% lidí, že jsou bez vyznání). U položky „Litujete někdy, že žijete se svým partnerem/kou ve společné domácnosti?“ byla přidána možnost odpovědi „Tato otázka se mě netýká (nebydlíme společně)“, protože se předpokládalo, že ne všichni respondenti v partnerském vztahu budou sdílet domácnost. Na začátek dotazníku byly přidány upřesňující položky dotazující se na věk, pohlaví a délku vztahu.

\section{Výzkumný vzorek}

Vzorek byl vybrán z obecné populace příležitostným výběrem. Data byla sesbírána pomocí internetového dotazníku. Dotazník byl šířen prostřednictvím Facebooku, dále emailem a dalšími internetovými komunikačními prostředky. Výzkumu se zúčastnilo celkem 298 respondentů, avšak 66 z nich uvedlo, že v současnosti nejsou v partnerském vztahu, proto ve výzkumu dále nepokračovali. Finální výzkumný vzorek byl tvořen 232 participanty, přičemž žen bylo $162(69,8 \%)$ a mužů 70 (30,2 \%). Průměrný věk byl 24 let $(\min =18, \max =72, \mathrm{SD}=6,97, \mathrm{Md}=22)$. Průměrná délka vztahu byla 4,2 let $(\min =0,1$, $\max =50, \mathrm{SD}=6,2)$.

\section{Použité metody}


K měření partnerské spokojenosti byla použita metoda RAS (Relationship Assessment Scale). Pro zjištění a ověření validity byla současně administrována i metoda RDAS (Revised Dyadic Assessment Scale) měřící partnerské přizpůsobení.

\section{Konfirmační faktorová analýza}

Faktorová struktura obou metod byla ověřena konfirmační faktorovu analýzou (CFA). Kvůli zešikmenému rozložení položek byla použita robustní metoda odhadu MLR (Robust Maximum Likelihood). Položka "Litujete někdy, že žijete se svým partnerem/kou ve společné domácnosti?" nebyla do faktorového modelu zařazena. Vzhledem k tomu, že velká část výzkumného vzorku (47,8 \%) zvolila možnost "Tato otázka se mě netýká", nebyla tato položka vzhledem $\mathrm{k}$ měřenému konstruktu relevantní. Tento jev mohl být způsobený metodou sběru dat. Na Facebooku, prostřednictvím kterého byl dotazník šířen, se vyskytuje mnoho mladých lidí, kterých se společné bydlení s partnerem netýká, což naznačuje i průměrný věk respondentů $(M=24, S D=6,97)$. Model CFA byl sestaven ze čtyř latentních faktorů a devatenácti položek: sedm položek sycených faktorem spokojenosti (RAS), tři položky sycené faktorem spokojenosti (RDAS), pět položek sycených faktorem shody (RDAS) a čtyři položky sycené faktorem soudržnosti (RDAS). V modelu jsme vzhledem $\mathrm{k}$ teoretickým předpokladům o souvislosti mezi konstrukty povolili korelace mezi faktory. Také jsme povolili korelaci reziduálních rozptylů položek P7 (Kolikje ve Vašem vztahu problémů?) a P9 (Jak často se spolu s partnerem/kou hádáte?). Tyto položky nenáleží ke stejné metodě, avšak obě jsou syceny faktorem partnerské spokojenosti. Z obsahového hlediska jsou si velmi podobné, také byly v rámci dotazníku zařazeny blízko sebe, a je tedy smysluplné, že byl mezi jejich rezidui systematický sdílený rozptyl. Korelace reziduí ostatních položek nebyly $\mathrm{v}$ modelu povoleny vzhledem $\mathrm{k}$ př́padnému snížení zobecnitelnosti modelu mimo data současné studie.

\section{Výsledky}

\section{Popisné statistiky}

Cílem výzkumné studie bylo zjistit a oveřit psychometrické vlastnosti metody Relationship Assessment Scale (RAS). Korigované korelace (korelace skóru položky s celou škálou s korekcí proti korelaci položky se sebou samou) se u některých položek ukázaly být poměrně nízké (nejnižší $r_{-} k o r=0,36$ pro položku „Rozhodnutí týkající se zaměstnání"). U většiny položek se však v rámci CFA ukázaly silné faktorové náboje a korelace mezi položkami také nabývaly přijatelných hodnot. Položka „Litujete někdy, že žijete se svým partnerem/kou ve společné domácnosti?" metody RDAS byla z důvodu chybějících hodnot $\mathrm{z}$ analýz vyloučena.

\section{Reliabilita}

Reliabilita metod byla odhadnuta pomocí ukazatele Cronbachova alfa. Pro metodu RAS $\alpha=0,89$, poukazující na vysokou vnitřní konzistenci např́íc položkami. U škály pro partnerskou spokojenost byla vnitřní konzistence odhadnuta jako $\alpha=0,70$, pro škálu partnerské shody $\alpha=0,65$ a škálu partnerského přizpůsobení $\alpha=0,75$. 
Tabulka 1: Popisné statistiky položek

\begin{tabular}{|c|c|c|c|c|c|c|}
\hline & Položky & Škála & M & SD & popularita & r_kor \\
\hline P1 & Do jaké míry naplňuje partner/ka Vaše potřeby? & 1 & 4,17 & 0,86 & 0,78 & 0,57 \\
\hline $\mathrm{P} 2$ & Jak jste obecně spokojen/a se svým vztahem? & 1 & 4,27 & 0,86 & 0,8 & 0,53 \\
\hline P3 & Jak dobrý je Váš vztah v porovnání s ostatními vztahy? & 1 & 4,4 & 0,81 & 0,81 & 0,44 \\
\hline $\mathrm{P} 4$ & $\begin{array}{l}\text { Jak často si přejete, abyste nebyl/a ve vztahu? } \\
\text { Do jaké míry naplňuje Váš vztah Vaše původní }\end{array}$ & 1 & 4,01 & 1,09 & 0,78 & 0,5 \\
\hline P5 & očekávání? & 1 & 4,63 & 0,69 & 0,81 & 0,36 \\
\hline P6 & Jak moc milujete svého partnera/svou partnerku? & 1 & 4,38 & 0,88 & 0,85 & 0,6 \\
\hline $\mathrm{P7}$ & Kolik je ve Vašem vztahu problémů? & 1 & 3,8 & 0,95 & 0,74 & 0,41 \\
\hline P8 & $\begin{array}{l}\text { Jak často uvažujete nebo mluvíte o odluce nebo } \\
\text { ukončení svého vztahu? }\end{array}$ & 2 & 4,03 & 0,92 & 0,83 & 0,72 \\
\hline P9 & Jak často se spolu s partnerem/kou hádáte? & 2 & 3,9 & 0,85 & 0,85 & 0,72 \\
\hline $\mathrm{P} 10$ & Jak často si s partnerem/kou „lezete na nervy“? & 2 & 4,06 & 0,93 & 0,88 & 0,6 \\
\hline P11 & Způsoby projevů náklonnosti & 3 & 4,26 & 0,98 & 0,74 & 0,53 \\
\hline $\mathrm{P} 12$ & Dělání významných rozhodnutí & 3 & 3,69 & 0,96 & 0,46 & 0,45 \\
\hline $\mathrm{P} 13$ & Sex & 3 & 3,72 & 0,84 & 0,67 & 0,41 \\
\hline $\mathrm{P} 14$ & Dodržování společenských pravidel & 3 & 3,92 & 0,82 & 0,6 & 0,48 \\
\hline $\mathrm{P} 15$ & Rozhodnutí týkající se zaměstnání & 3 & 3,97 & 0,78 & 0,72 & 0,56 \\
\hline P16 & Věnujete se společně s partnerem nějakému zájmu? & 4 & 2,29 & 0,8 & 0,32 & 0,68 \\
\hline $\mathrm{P} 17$ & Máte podnětnou diskusi? & 4 & 3,36 & 1,09 & 0,81 & 0,62 \\
\hline P18 & Děláte na něčem společně? & 4 & 2,98 & 1,14 & 0,93 & 0,65 \\
\hline P19 & V klidu si o něčem promluvíte? & 4 & 3,58 & 1,08 & 0,44 & 0,66 \\
\hline
\end{tabular}

Poznámka: 1 = RAS spokojenost, 2 = RDAS spokojenost, 3 = RDAS shoda, 4 = RDAS soudržnost

\section{Konstruktová validita}

Co se týče modelu konfirmační faktorové analýzy, signifikantní výsledek chí-kvadrát testu $\left(\chi^{2}(146)=300 ; \mathrm{p}<0,001\right)$ by mohl poukazovat na model neuspokojivě reprezentující data, tento výsledek však mohl být ovlivněn velikostí výzkumného vzorku. U ukazatelů shody modelu s daty hodnota RMSEA = 0,067 (90\%CI: 0,056; 0,078) naznačovala ucházející shodu modelu s pozorovanými daty, stejně jako $\mathrm{TLI}=0,90$ a $\mathrm{CFI}=0,92$. Většina položek byla faktory silně sycena (viz níže tabulka faktorových nábojů), u položek č. 9, 13, 14, 15 a 17 se ukázaly nižší faktorové náboje. U těchto pěti položek byly odhadnuty také vysoké specifické rozptyly. Mezi faktory metody RDAS se ukázaly pozitivní korelace: $r=0,70$ (shoda a soudržnost), $r=0,50$ (soudržnost a spokojenost), $r=0,82$ (shoda a spokojenost). Prostřednictvím konfirmační faktorové analýzy byly také zjištěny korelace mezi jednotlivými dimenzemi obou metod. Korelace mezi faktorem partnerské spokojenosti (RAS) a partnerské spokojenosti (RDAS) byla zjištěna $r=0,93$, vztah mezi těmito dimenzemi odpovídal hypotéze o vysoké pozitivní korelaci, jelikož jde o stejný konstrukt měřený dvěma různými metodami. Vysoká pozitivní korelace byla zjištěna také mezi faktorem spokojenosti (RAS) a faktorem partnerské shody, $r=0,88$, což bylo v rozporu s naším předpokladem. Mezi faktorem spokojenosti (RAS) a faktorem partnerské soudržnosti (RDAS) byla korelace $r=0,58$. 
Modifikační indexy ukázaly na možné systematické reziduální sdílené rozptyly mezi některými položkami (P7 - P9, P9 - P19, P2 - P9, P7 - P19). Na základě toho lze soudit, že by korelace reziduí těchto položek zlepšily celkovou shodu modelu s daty. Jediná korelace, která však byla mezi rezidui položek v modelu povolena, byla mezi položkami P7 (Kolikje ve Vašem vztahu problémů?) a P9 (Jak často se spolu s partnerem/kou hádáte?) a hodnota korelace jejich reziduí byla odhadnuta jako $r=0,30$. Povolení korelace reziduí položek P7 a P9 nezpůsobilo významnou změnu ve shodě modelu $s$ daty, RMSEA $=0,064$ (90\%CI: 0,052; 0,075), TLI= 0,92, CFI= 0,93.

Další analýzy také ukázaly, že partnerská spokojenost se nelišila v závislosti na pohlaví, $t(143)=-0,123, p=0,90, d=-0,02$. Silný vztah nebyl pozorován mezi délkou vztahu a partnerskou spokojeností $(r=-0,18, p=0,06)$ ani mezi spokojeností a věkem respondenta $(r=-0,12, p=0,07)$.

Obrázek 1: Model konfirmační faktorové analýzy

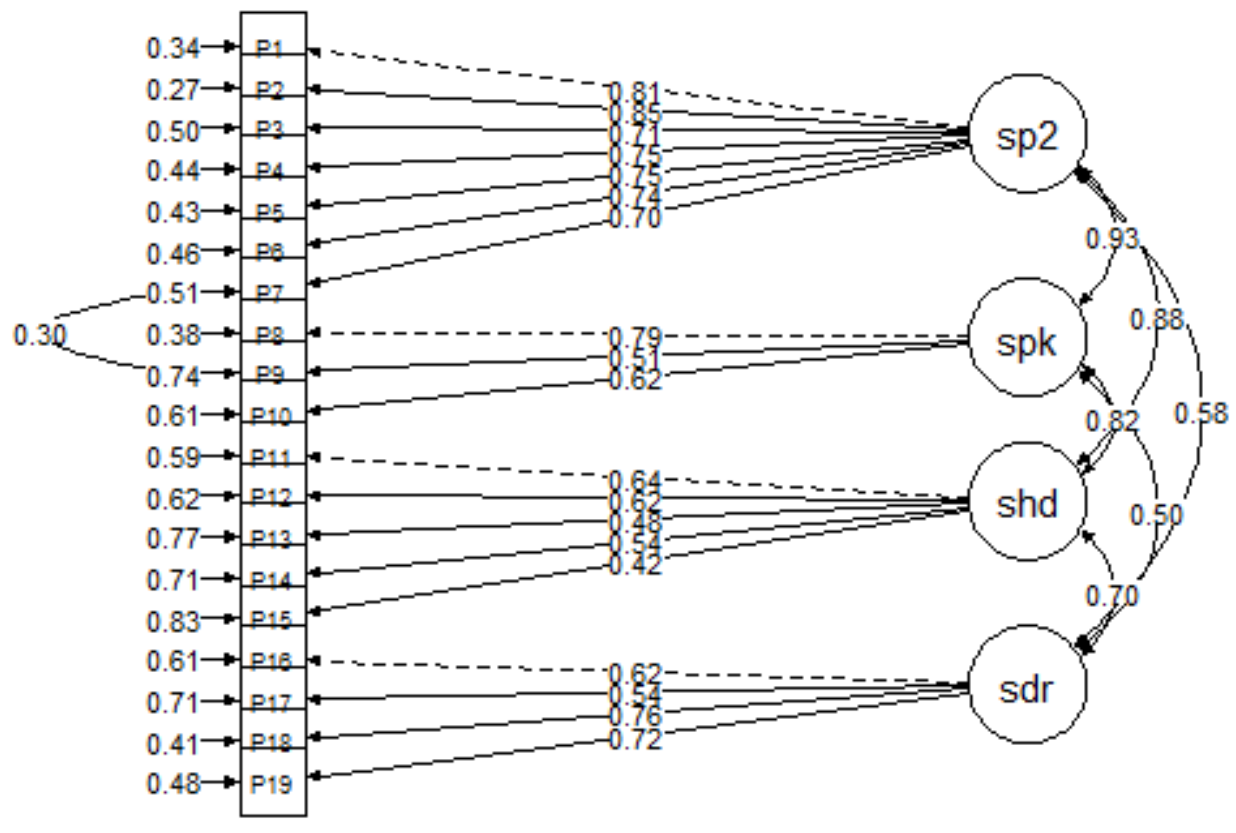

Poznámka: faktor "sp2“ = RAS spokojenost, faktor „spk“ = RDAS spokojenost, faktor „shd“ = RDAS shoda, faktor „sdr" = RDAS soudržnost

Jelikož byl výzkumný vzorek v určitých charakteristikách specifický (např́íklad v nízkém věku respondentů nebo nesdílení společné domácnosti s partnerem), některé položky se na tomto výzkumném vzorku neukázaly jako přiliš funkční. U položek, prostřednictvím kterých byli respondenti dotazováni na shodu mezi nimi a partnerem v otázkách zaměstnání, dodržování společenských pravidel, dělání významných rozhodnutí, sexu, a kde byla zjištována četnost podnětné diskuze a hádek, se v modelu konfirmační faktorové analýzy ukázaly nízké náboje a vysoké specifické rozptyly jednotlivých položek. Ukázaly 
se také neočekávaně vysoké korelace mezi partnerskou spokojeností a partnerskou shodou poukazující na možný překryv těchto dvou měřených konstruktů.

Tabulka 2: Faktorové náboje: RAS(1) spokojenost, RDAS(1) spokojenost, RDAS(2) shoda, RDAS(3) soudržnost

\begin{tabular}{|c|c|c|c|c|c|}
\hline & Položky & RAS(1) & $\operatorname{RDAS}(1)$ & $\operatorname{RDAS}(2)$ & RDAS(3) \\
\hline $\mathrm{P} 1$ & Do jaké míry naplňuje partner/ka Vaše potřeby? & 0,81 & & & \\
\hline $\mathrm{P} 2$ & Jak jste obecně spokojen/a se svým vztahem? & 0,85 & & & \\
\hline P3 & Jak dobrý je Váš vztah v porovnání s ostatními vztahy? & 0,71 & & & \\
\hline $\mathrm{P} 4$ & Jak často si přejete, abyste nebyl/a ve vztahu? & 0,75 & & & \\
\hline P5 & Do jaké míry naplňuje Váš vztah Vaše původní očekávání? & 0,75 & & & \\
\hline P6 & Jak moc milujete svého partnera/svou partnerku? & 0,74 & & & \\
\hline $\mathrm{P} 7$ & Kolik je ve Vašem vztahu problémů? & 0,70 & & & \\
\hline P8 & $\begin{array}{l}\text { Jak často uvažujete nebo mluvíte o odluce nebo } \\
\text { ukončení svého vztahu? }\end{array}$ & & 0,79 & & \\
\hline P9 & Jak často se spolu s partnerem/kou hádáte? & & 0,51 & & \\
\hline $\mathrm{P} 10$ & Jak často si s partnerem/kou „lezete na nervy“? & & 0,62 & & \\
\hline P11 & Způsoby projevů náklonnosti & & & 0,64 & \\
\hline $\mathrm{P} 12$ & Dělání významných rozhodnutí & & & 0,62 & \\
\hline P13 & Sex & & & 0,48 & \\
\hline P14 & Dodržování společenských pravidel & & & 0,54 & \\
\hline P15 & Rozhodnutí týkající se zaměstnání & & & 0,42 & \\
\hline P16 & Věnujete se společně s partnerem nějakému zájmu? & & & & 0,62 \\
\hline P17 & Máte podnětnou diskusi? & & & & 0,54 \\
\hline P18 & Děláte na něčem společně? & & & & 0,76 \\
\hline P19 & V klidu si o něčem promluvíte? & & & & 0,72 \\
\hline
\end{tabular}

\section{Navrhovaná revize modelu}

Vzhledem k problematickým aspektům CFA modelu byl navržen nový model, do kterého nebyly zahrnuty položky P9, P12, P13, P14, P15 a P17. Nový faktorový model byl sestaven ze dvou latentních faktorů, kterými jsou partnerská spokojenost a partnerská soudržnost a třinácti položek sycených těmito faktory. Faktorová struktura modelu se dvěma faktory byla navržena z důvodu vysokých korelací mezi faktory partnerské spokojenosti a shody. Co se týče výsledků, p-hodnota chí-kvadrát testu $\left(\chi^{2}(64)=136,9 ; p<0,001\right)$ by mohla poukazovat na špatnou shodu modelu s daty, výsledek však mohl být ovlivněn velikostí výzkumného vzorku. Hodnota RMSEA = 0,07 (90\%CI: 0,054; 0,086) implikuje ucházející shodu modelu s daty, hodnoty indexů TLI $=0,94$ a CFI $=0,95$ poukazují na model velmi dobře reprezentující data. Co se týče faktorových nábojů, všechny byly odhadnuty jako poměrně vysoké. Hodnoty specifických rozptylů položek byly u většiny položek přijatelné. Korelace mezi faktorem partnerské spokojenosti a soudržnosti byla zjištěna $r=0,58$.

Obrázek 2: Model konfirmační faktorové analýzy 


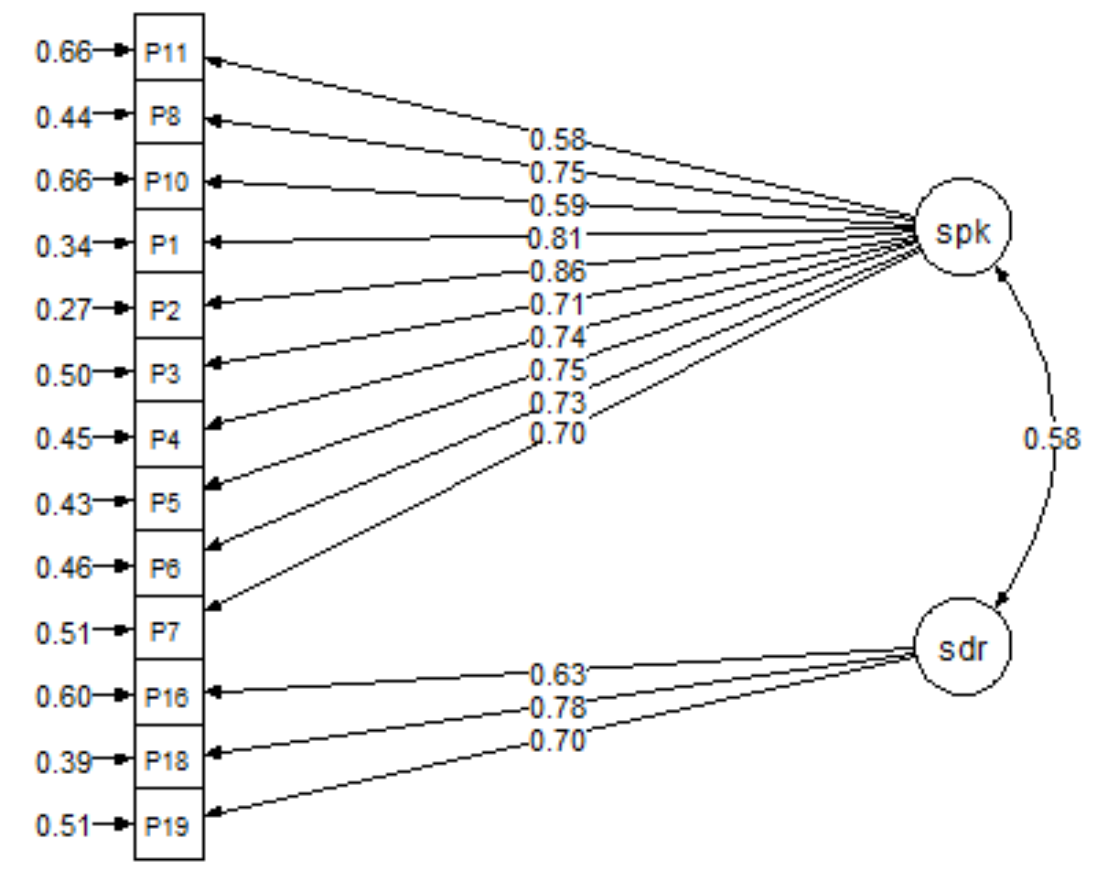

\section{Diskuze}

Předmětem výzkumné studie bylo ověření reliability a konstruktové validity metody Relationship Assessment Scale (RAS) za využití Revised dyadic adjustment scale (RDAS). Analýza reliability jako vnitřní konzistence metod ukázala, že položky metody RAS a RDAS mají v rámci současné studie přijatelnou vnitřní konzistenci. Nižší hodnota pro reliabilitu škály partnerské shody mohla být způsobena některými položkami, které na výzkumném vzorku nefungovaly dobře.

Výsledky faktorové analýzy byly $\mathrm{v}$ souladu $\mathrm{s}$ předpokladem, že mezi faktorem spokojenosti měřeným metodou RAS a faktorem spokojenosti měřeným metodou RDAS je silný pozitivní vztah. Toto zjištění je v souladu s výsledky Hendrickové (1988), která mezi faktory taktéž objevila silný pozitivní vztah. Tento výsledek zároveň podpořil hypotézu o konstruktové validitě metody RAS. Mezi faktorem partnerské soudržnosti metody RDAS a faktorem spokojenosti metody RAS se ukázal středně silný pozitivní vztah, který též podpořil naši hypotézu o vztahu těchto dvou dimenzí a je v souladu s dřivějším výzkumem (Hendrick, 1988). Mezi faktorem partnerské shody metody RDAS a spokojenosti metody RAS se ukázala silná pozitivní korelace, což bylo v rozporu s naším předpokladem o vztahu těchto faktorů.

Vzhledem $\mathrm{k}$ nepředpokládaným vysokým korelacím mezi dimenzemi partnerská spokojenost a partnerská shoda byl navržen nový dvou-faktorový model, ze kterého byly oproti původnímu modelu vyřazeny nefunkční položky. Vzhledem $\mathrm{k}$ charakteristikám výzkumného vzorku se nefunkčnost položek zdá být logická - pro mladé lidi nemusejí být 
tyto otázky týkající se rozhodnutí $\mathrm{v}$ oblasti zaměstnání, významných rozhodnutí a společenských pravidel relevantní či podstatné. Možným vysvětlením by mohl být fakt, že pro období tzv. vynořující se dospělosti je příznačný aspekt nestability, touhy po objevování a vážení si své svobody (Arnett, 2015). Pro mladé lidi tedy uvedené oblasti nemusely fungovat jako ukazatel shody s partnerem. Zatímco průměrný věk výzkumného vzorku naší studie byl 24 let a $48 \%$ respondentů uvedlo, že s partnerem nesdílí společnou domácnost, studie Turliac \& Muraru (2016), ve které byla podpořena hypotéza o faktorové struktuře metody RDAS, byla postavena na vzorku již starších manželských párů. Co se týče nefunkčních položek dotazujících se na četnost hádek a shodu v oblasti sexuální aktivity, tyto charakteristiky vztahu by mohly být považovány spíše za důsledek nespokojenosti ve vztahu nežli jako součást měřeného konstruktu. Nový faktorový model ukázal dobrou shodu s daty a hypotéza o středně silné korelaci mezi partnerskou spokojeností a soudržností byla podpořena.

Ačkoliv partnerská spokojenost a shoda bývají považovány za odlišné charakteristiky partnerského vztahu (Busby et al., 1995; Cramer, 2001; Heyman, Sayers \& Bellack, 1994), v rámci našeho výzkumného souboru byl odhadnut silný pozitivní vztah mezi těmito dvěma latentními proměnnými poukazující na jeden společný faktor. Vysvětlení ohledně shody partnerské spokojenosti $s$ dalšími měřenými charakteristikami partnerského vztahu nabízí Gottman (1990), který ve své knize shrnuje problematiku zkoumání manželské spokojenosti. Podle Gottmana (1990) je v rámci výzkumu pro respondenty problematické rozlišovat mezi spokojeností a dalšími vlastnostmi vztahu. Tento fenomén vysvětluje haló efektem: ten, kdo je ve svém vztahu spokojený má tendenci vypovídat o svém vnímání tohoto vztahu zkresleně a přehnaně pozitivně, zatímco nespokojení lidé popisují vztah zkresleně opačným způsobem, tedy př́liš negativně. Přestože tedy z hlediska teorie mezi partnerskou spokojeností a shodou rozlišujeme, je možné, že na úrovni dotazníku a jednotlivých položek se tyto rozdíly př́liš neodráží.

\section{Limity studie}

Vzhledem k tomu, že sběr dat probíhal přes internet, nebylo možné kontrolovat, kdo vstupoval do výzkumného vzorku, ani mít přehled o návratnosti dotazníku. Kvưli tomu může být použití sociální sítě ke sběru dat vnímáno jako jeden z limitů studie. Limitem studie je také nízký věk respondentů, který mohl ovlivnit výsledky. Sociální sítě, kde byl sběr dat převážně realizován, používají $\mathrm{Z}$ větši části mladí lidé. $\mathrm{Z}$ toho důvodu byl také výzkumný vzorek tvořen převážně mladými lidmi a získali jsme tak málo informací od starších lidí, jejichž pojetí partnerské spokojenosti se může v určitých aspektech lišit od zkušenosti mladších respondentů. Internetový sběr způsobil i nevyvážený poměr žen a mužů, o respondentech mužského pohlaví jsme tedy nezískali tolik informací. Za př́ípadný limit studie může být považována také citlivost tématu, která mohla ovlivnit odpovědi respondentů. Vzhledem k tomu, že informace o partnerské spokojenosti byly získávány prostřednictvím subjektivních výpovědí, je možné, že respondenti nevypovídali v souladu se skutečností. Vaughnová a Baierová (1999) při validizaci Relationship Assessment Scale metody zvažovaly limit neexistujícího cut-skóru mezi spokojenými a nespokojenými 
lidmi. Stejným nedostatkem by se dalo argumentovat i v našem př́ípadě, kdy sice vy̌šší skóre indikuje vyšší partnerskou spokojenost, avšak není stanovena žádná hranice, dle které by se dalo určit, zda člověk je či není ve vztahu spokojený.

Další výzkum by se v budoucnu mohl věnovat vztahu mezi zjištěnou spokojeností měřenou př́mo na párech, a to nejen heterosexuálních, ale i homosexuálních či rasově smíšených, nebo brát v potaz nejrůznější koncepty, jako vliv osobnostních charakteristik. Zvážit by se mohla i role spokojenosti ve vztahu jako prediktoru rozchodu, čímž by byla ověřena prediktivní validita metody. 


\section{Zdroje}

Arnett, J. J. (2015). Emerging adulthood: the winding road from the late teens through the twenties. New York: Oxford University Press.

Busby, D. M., Crane, D. R., Larson, J. H., \& Christensen, C. (1995). A revision of the Dyadic Adjustment Scale for use with distressed and nondistressed couples: Construct hierarchy and multidimensional scales. Journal of Marital and Family Therapy, 21, 289-308.

Cramer, D. (2001). Consensus Change, Conflict, and Relationship Satisfaction in Romantic Relationship. The Journal of Psychology, 153(3), 313-320.

Daňsová, P. (2015). Mateřské sebehodnocení v těhotenství: souvislost $\mathrm{s}$ vybranými charakteristikami ženy a partnerského vztahu. Diplomová práce. Masarykova univerzita.

Gottman, J. M. (1990). How marriages change. In G. R. Patterson (Ed.), Depression and aggression in family interaction (pp. 75-101). Hillsdale, NJ: Erlbaum.

Hamplová, D. \& Řeháková, B. (2009). Česká religiozita na počátku 3. tisíciletí: výsledky Mezinárodního programu sociálního výzkumu ISSP 2008 - Náboženství. Praha: Sociologický ústav AV ČR.

Hendrick, S. (1988). A Generic Measure of Relationship Satisfaction. Journal of Marriage and the Family 50(1), 93-98.

Heyman, R. E., Sayers, S. L., \& Bellack, A. S. (1994). Global Marital Satisfaction Versus Marital Adjustment: An Empirical Comparison of Three Measures. Journal of Family Psychology, $8(4), 432-446$.

Muraru, A. A., Turliuc, M. N. (2013). Predictors of Marital Adjustment: Are There Any Differences Between Women and Men? Europe's Journal of Psychology, 9(3), 427-442.

Olson, D. H., \& Gorall, D. M. (2003). Circumplex model of marital and family systems. In F. Walsh (Ed.), Normal family processes (pp. 514-547). New York, NY: Guilford Press.

Renshaw, K. D., McKnight, P., Caska, C. M., Blais, R. K. (2010). The utility of the relationship assessment scale in multiple-types relationships. Journal of Social and Personal Relationships, 28(4), 435-447.

Spanier, G. B. (1976). Measuring dyadic adjustment: New scales for assessing the quality of marriage and similar dyads. Journal of Marriage and the Family, 38(1), 15-28.

Spanier, G. B. (1985). Improve, refine, recast, expand, clarify. Don't abandon. Journal of Marriage and Family, 47(4), 1073-1074.

Thibaut, J. W., Kelly, H. H. (1959). Social psychology of groups. New York: Wiley. 
Turliuc, M. N., Muraru, A. A. (2013). Psychometric Properties of Revised Dyadic Adjustment Scale on a Sample of Married Adults. Journal of Psychological and Educational Research, 21(1), 4976.

Vaughn, M. J., Baier, M. E. M. (1999). Reliability and Validity of Relationship Assessment Scale. American Journal of Family Therapy, 27(2), 137. 


\title{
Nikol Kvardová, Monika Radimecká, Marie Drápalová, Jan Širůček (2019): Reliability and construct validity of Relationship Assessment Scale
}

\begin{abstract}
This article is focused on selected psychometric properties of the Relationship Assessment Scale (RAS) which is used for the assessment of relationship satisfaction. We investigated internal consistency as an indicator of reliability, and construct validity of the RAS questionnaire by assessing its associations with latent factors of satisfaction, consensus, and cohesion in the relationship which are the dimensions of the Revised Dyadic Adjustment Scale (RDAS). The RDAS questionnaire was designed to measure adjustment in a relationship. In order to investigate reliability and validity, we collected data from 232 respondents via internet. Reliability of the questionnaire was acceptable for application in research. Association between the RAS satisfaction, the RDAS satisfaction, and the RDAS cohesion supported the construct validity of the RAS questionnaire. A strong positive association between the RAS satisfaction and the RDAS cohesion did not support the construct validity, results showed that there was a possible overlap between these two constructs in our study. However, results could have been impacted by the use of the RDAS Relationship Consensus Scale which did not function as a reliable indicator of the consensus in our sample. Based on the results, we proposed a revised model.
\end{abstract}

Keywords: Relationship Assessment Scale; relationship satisfaction, psychometric properties 


\section{Příloha č. 1: Originální verze metody RAS}

1 . How well does your partner meet your needs?

2. In general, how satisfied are you with your relationship?

3. How good is your relationship compared to most?

4. How often do you wish you hadn't gotten into this relationship?

5 . To what extent has your relationship met yout original expectations?

6. How much do you love your partner?

7. How many problems are there in your relationship?

\section{Př́íloha č. 2: Adaptace metody RAS do českého jazyka}

1. Do jaké míry naplňuje partner/ka Vaše potřeby? Od 1 (vůbec) do 5 (zcela)

2. Jak jste obecně spokojen/a se svým vztahem? Od 1 (vůbec) do 5 (zcela)

3. Jak dobrý je Váš vztah v porovnání s ostatními vztahy? Od 1 (nejhorší) do 5 (nejlepší)

4. Jak často si přejete, abyste nebyl/a ve vztahu? Od 1 (nikdy) do 5 (pořád)

5. Do jaké míry naplňuje Váš vztah Vaše původní očekávání? Od 1 (vůbec) do 5 (zcela)

6. Jak moc milujete svého partnera/svou partnerku? Od 1 (vůbec) do 5 (zcela)

7. Kolik je ve Vašem vztahu problémů? Od 1 (žádné) do 5 (hodně)

\section{Př́loha č. 3: Adaptace metody RDAS do českého jazyka}

Níže prosím označte, do jaké míry dochází mezi Vámi a Vaším partnerem ke shodě či rozepři v následujících oblastech:

1. Způsoby projevů náklonnosti (kde, kdy a jakým způsobem si projevujete náklonnost - např. lichotkami, pozorností, dárky, fyzickým kontaktem apod.)

5 -V̌̌dy se shodneme 4 - téměr vždy se shodneme 3 - občas se shodneme 2 - často se neshodneme 1 -téměř nikdy se neshodneme 0 -nikdy se neshodneme

2. Dělání významných rozhodnutí

5 -V̌̌dy se shodneme 4 - téměr vždy se shodneme 3 - občas se shodneme 2 - často se neshodneme 1 -téměr̆ nikdy se neshodneme 0 -nikdy se neshodneme

3. Sex

5 -Vždy se shodneme 4 - téměr vždy se shodneme $\quad 3$ - občas se shodneme 2 - často se neshodneme 1 -téměr̆ nikdy se neshodneme 0 -nikdy se neshodneme

4. Dodržování společenských pravidel (správné nebo vhodné chování) 
N. Kvardová, M. Radimecká, M. Drápalová, J. Širůček: Reliabilita a konstruktová validita metody Relationship Assessment Scale

5 - Vždy se shodneme $\quad 4$ - téměr vždy se shodneme $\quad 3$ - občas se shodneme 2 - často se neshodneme 1 -téměr nikdy se neshodneme 0 -nikdy se neshodneme

5. Rozhodnutí týkající se zaměstnání

5 - Vždy se shodneme 4 - téměr vždy se shodneme $\quad 3$ - občas se shodneme 2 - často se neshodneme 1 -téměr nikdy se neshodneme 0 -nikdy se neshodneme

6. Jak často uvažujete nebo mluvíte o odluce nebo ukončení svého vztahu?

0 - Neustále 1 -většinu času/téměř neustále 2 -spíš ano než ne 3 -občas

4 - zrí́dka $5-n i k d y$

7. Jak často se spolu s partnerem/kou hádáte?

0 - Neustále 1 -většinu času/téměř neustále 2 -spíš ano nežne 3 -občas

4-zř́́dka 5 - nikdy

8. Litujete někdy, že žijete se svým partnerem/kou ve společné domácnosti?

0 - Neustále 1 -většinu času/téměr̆ neustále 2 -spíš ano než ne 3 -občas

4 - zrí́dka $5-n i k d y$

9. Jak často si s partnerem/kou „lezete na nervy“?

0 - Neustále 1 -většinu času/téměř neustále 2 -spíš ano než ne 3 -občas

4-zř́dka 5-nikdy

10. Věnujete se společně s partnerem nějakému zájmu?

4-Každýden $\quad 3$-skoro každýden $\quad 2$-občas $\quad 1$-zř́ddka $\quad 0$-nikdy

Jak často dochází mezi Vámi a Vaším partnerem k následujícím situacím?

11. Máte podnětnou diskusi.

0 - Nikdy 1 -méně než jednou za měsíc 2 - jednou nebo dvakrát za měsíc

3 -jednou nebo dvakrát týdně $\quad 4$-jednou denně $\quad 5$-častěji než jednou denně

12. Děláte na něčem společně.

0-Nikdy 1 - méně než jednou za měsíc 2 - jednou nebo dvakrát za měsíc

3 -jednou nebo dvakrát týdně $\quad 4$-jednou denně $\quad 5$-častěji než jednou denně

13. V klidu si o něčem promluvíte.

0-Nikdy 1 -méně než jednou za měsíc 2 - jednou nebo dvakrát za měsíc

3 -jednou nebo dvakrát týdně $\quad 4$-jednou denně $\quad 5$-častěji než jednou denně 